\title{
FITOPLANKTON SEBAGAI BIOINDIKATOR PENCEMARAN ORGANIK DI PERAIRAN SUNGAI MUSI BAGIAN HILIR SUMATRA SELATAN
}

\section{PHYTOPLANKTON AS A BIOINDICATOR OF ORGANIC POLLUTION IN THE WATERS OF MUSI RIVER DOWNSTREAM SOUTH SUMATRA}

\author{
Riris Aryawati*, T. Zia Ulqodry, Isnaini, \& Heron Surbakti \\ Program Studi Ilmu Kelautan, Fakultas MIPA, Universitas Sriwijaya, Indralaya, 30862, Indonesia \\ *E-mail: ririsaryawati@yahoo.com
}

\begin{abstract}
The Musi River is the largest and longest river in South Sumatra. The development of population activities in the Musi River Basin can affect river water quality and can cause pollution. The high level of industrial activity and households along the Musi River causes a decrease in environmental quality in the Musi River Basin. The declining quality of aquatic environment can be seen from the presence of phytoplankton. Based on this, further research is needed to determine the extent of pollution in the Musi River Basin. The purpose of this study is to assess saprobitas along the Musi River Basin based on SI (Saprobic Index) value and knowing the level of water pollution using saprobitas water assessment. This study uses plankton as a bioindicator of aquatic organic pollution. This study uses an exploratory design with survey methods, and the determination of sampling stations by purposive sampling method. The results showed abundance of phytoplankton in the waters of the Musi River in the range of 123 to 2581 cells.liter ${ }^{-1}$ or an average of 1397 cells.liter $^{-1}$. The Saprobic index in the waters of the Musi River ranges from 0.631 to 1, classified in the phases of the microbial, namely $\beta$ Mesosaprobic, so that the waters of the Musi River are classified as mild.
\end{abstract}

Keywords: Musi river, pollution, saprobitas

\begin{abstract}
ABSTRAK
Sungai Musi merupakan sungai terbesar dan terpanjang di Sumatra Selatan. Berkembangnya kegiatan penduduk di Daerah Aliran Sungai (DAS) Musi dapat berpengaruh terhadap kualitas air sungai dan dapat menyebabkan terjadinya pencemaran. Tingginya aktivitas industri maupun rumah tangga di sepanjang Sungai Musi menyebabkan menurunnya kualitas lingkungan di DAS Musi. Menurunnya kualitas lingkungan perairan dapat dilihat dari keberadaan fitoplanktonnya. Berdasarkan hal tersebut, maka perlu dilakukan penelitian lebih lanjut untuk mengetahui seberapa besar tingkat pencemaran yang terjadi di DAS Musi. Tujuan dari penelitian ini adalah untuk mengkaji dan mengetahui tingkat saprobitas di sepanjang DAS Musi bagian hilir berdasarkan nilai SI (Saprobik Indeks), serta mengetahui tingkat pencemaran air menggunakan penilaian saprobitas perairan. Penelitian ini menggunakan plankton sebagai bioindikator pencemaran organik perairan. Penelitian ini menggunakan rancangan eksplorasi dengan metode survei, dan penetapan stasiun pengambilan sampel dengan metode purposive sampling. Hasil penelitian menunjukkan kelimpahan fitoplankton di perairan Sungai Musi pada rentang 123-2581 sel/liter atau rata-rata sebesar 1397 sel/liter. Indeks Saprobik di perairan Sungai Musi berkisar antara 0,63-1, digolongkan pada fasesaprobik, yaitu $\beta$ Mesosaprobik, sehingga pada perairan Sungai Musi digolongkan pada tingkat pencemaran ringan.
\end{abstract}

Kata Kunci: DAS Musi, pencemaran, saprobitas

\section{PENDAHULUAN}

Sungai Musi merupakan salah satu sungai terpanjang di Indonesia. Sungai Musi ini memiliki panjang $750 \mathrm{~km}$, dengan debit air berkisar $2.700 \mathrm{~m} 3 /$ detik pada musim kemarau hingga $4000 \mathrm{~m} 3 /$ detik pada musim hujan (Pemprov Sumsel, 1997). Berkembangnya kegiatan penduduk di Daerah Aliran Sungai (DAS) Musi, seperti 
bertambahnya permukiman penduduk, kegiatan industri, dan kegiatan pertanian dapat berpengaruh terhadap kualitas air sungai. Berbagai kegiatan di sepanjang aliran sungai menghasilkan bahan pencemar berupa limbah organik dan anorganik. Cemaran limbah tersebut mengakibatkan gangguan serta perubahan fisik, kimia dan biologi pada perairan sungai tersebut dan akhirnya menyebabkan pencemaran. Rudiyanti (2009) menyatakan bahwa degradasi kualitas air dapat terjadi akibat adanya perubahan parameter kualitas air yang dapat disebabkan oleh adanya aktivitas pembuangan limbah, baik limbah pabrik/industri, pertanian, maupun limbah domestik dari suatu pemukiman penduduk ke dalam badan air suatu perairan. Sejalan dengan pernyataan Hutabarat et al. (2013), yang menyatakan bahwa perairan Sungai Babon secara nyata telah menerima limbah yang berasal dari kegiatan industri yang berada di sekitar sungai Babon dan limbah yang berasal dari kegiatan rumah tangga (domestik). Keadaan ini diduga menyebabkan menurunnya kualitas lingkungan muara Sungai Babon.

Lingkungan dikatakan tercemar apabila sudah tidak sesuai lagi dengan peruntukannya, lingkungan tersebut sudah tidak bisa digunakan lagi sebagai tempat untuk hidup dan berkembang biak oleh makhluk hidup atau lainnya. Pengukuran parameter fisika dan kimia hanya dapat menggambarkan kualitas lingkungan pada waktu tertentu. Indikator biologi dapat memantau secara kontinu dan merupakan petunjuk yang mudah untuk memantau terjadinya pencemaran. Keberadaan organisme perairan dapat digunakan sebagai indikator terhadap pencemaran air selain indikator kimia dan fisika. Menurut Nybakken (1992) dan Nontji (2005) organisme perairan dapat digunakan sebagai indikator pencemaran karena habitat, mobilitas dan umurnya yang relatif lama mendiami suatu wilayah perairan.

Nilai pendekatan terhadap besarnya penurunan kualitas perairan suatu wilayah dinyatakan dalam suatu saprobitas kualitas perairan. Saprobitas kualitas perairan (water quality) disusun berdasarkan perubahan parameter fisika dan kimia yang diduga merupakan parameter penentu terhadap perubahan kondisi perairan. Parameter fisika kimia menggambarkan perubahan lingkungan pada saat tertentu (temporer) sehingga untuk perairan dinamis kurang memberikan gambaran sesungguhnya. Saprobitas dapat diukur dengan indikator plankton, karena setiap jenis plankton merupakan penyusun dari kelompok saprobitas tertentu yang akan berpengaruh terhadap nilai saprobitas (Rudiyanti, 2009; Hutabarat et al., 2013; Rasyid et al., 2018). Penelitian yang dilakukan Hutabarat et al. (2013) memperlihatkan bahwa fitoplankton dapat digunakan sebagai bioindikator pencemaran organik perairan yang hasilnya menunjukkan kualitas perairan muara Sungai Babon termasuk dalam tingkat $\alpha$ Mesosaprobik atau dalam kondisi tercemar sedang hingga berat.

Berdasarkan uraian di atas, dapat diduga telah terjadi pencemaran bahan organik oleh adanya limbah yang berasal dari aktivitas di darat yang masuk ke dalam kolom perairan. Kondisi ini hampir sama dengan yang terjadi di perairan DAS Musi. Oleh karenanya, dalam mengetahui seberapa besar tingkat pencemaran organik yang terjadi di DAS Musi khususnya di bagian hilir, maka perlu dilakukan penelitian ini. Adapun tujuan dari penelitian ini adalah untuk mengkaji dan mengetahui jenis-jenis fitoplankton yang terdapat di perairan Sungai Musi bagian hilir serta menentukan tingkat pencemaran perairan dengan SI.

\section{METODE PENELITIAN}

Penelitian dilakukan di perairan Sungai Musi bagian hilir hingga muara Sungai Musi, Sumatra Selatan dengan 14 stasiun (Gambar 1). Pengambilan data dilakukan menggunakan kapal nelayan. 


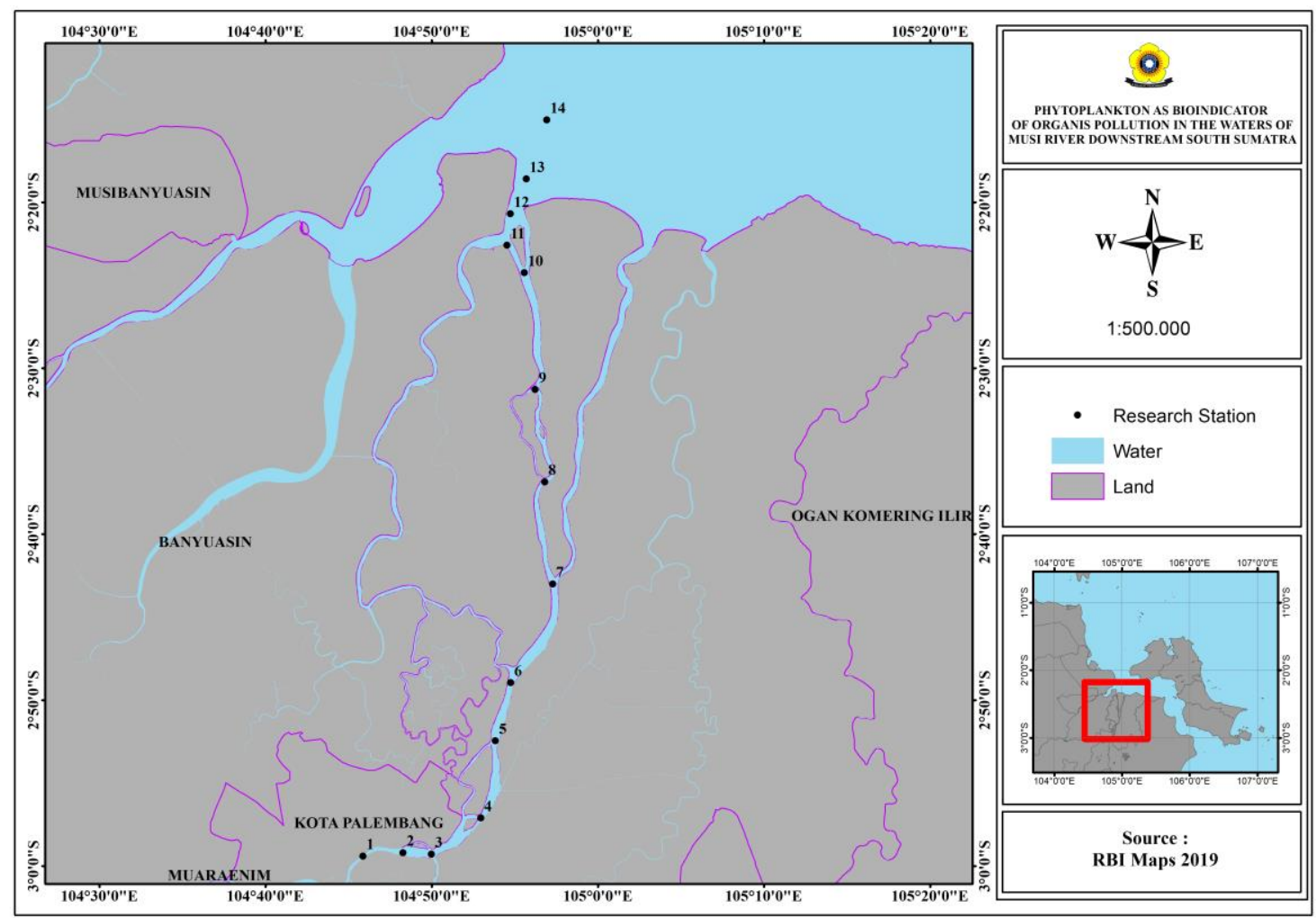

Gambar 1. Lokasi penelitian di perairan Sungai Musi bagian hilir hingga muara Sungai Musi, Sumatra Selatan.

Figure 1. Research locations in the waters of the Musi River downstream to the mouth of the Musi River, South Sumatra.

\subsection{Pengambilan Sampel Air dan Analisis Nutrien}

Sampel air diambil dengan menggunakan water sampler kapasitas 2,2 1 pada bagian permukaan air. Sampel air yang didapat kemudian dimasukkan dalam botol sampel dan disimpan dalam coolbox yang telah berisi es batu sebagai pengawet. Sampel air kemudian dibawa ke laboratorium untuk dianalisis kandungan nitrat dan fosfatnya. Pengukuran konsentrasi nitrat dilakukan berdasarkan metode reduksi kadmium (SNI 6989.79:2011), sedangkan konsentrasi fosfat berdasarkan metode asam askorbid (SNI 066989.31-2005).

\subsection{Pengambilan Sampel dan Analisis Komposisi Fitoplankton \\ Contoh fitoplankton diambil dengan} menggunakan jaring yang berbentuk kerucut dengan diameter $30 \mathrm{~cm}$ dan mata jaring 30 $\mu \mathrm{m}$. Jaring ditarik secara vertikal pada kedalaman $2 \mathrm{~m}$ ke permukaan. Contoh plankton yang diperoleh disimpan dalam botol sampel dan diberi larutan pengawet formalin hingga konsentrasi formalin dalam botol contoh mencapai $4 \%$.

Cacahan fitoplankton dilakukan melalui fraksi sebuah stempel pipette dan dinyatakan dalam sel/L. Fitoplankton diamati di bawah mikroskop, kemudian ditentukan jenis-jenis fitoplankton dengan menggunakan bantuan buku identifikasi fitoplankton (Newell \& Newell, 1977; Tomas, 1997). Data yang diperoleh selanjutnya dianalisis kelimpahannya dengan menggunakan rumus berikut (APHA, 1992):

$$
N=\frac{n}{p} x \frac{l_{S R}}{l_{P}} x \frac{V_{l}}{V_{S R C}} x \frac{1}{V_{T}}
$$


Keterangan: $\mathrm{N}=$ kelimpahan Plankton (sel.m $\left.{ }^{1}\right) ; \mathrm{p}=$ jumlah lapang pandang yang diamati; $\mathrm{n}=$ jumlah plankton yang tercacah $(\mathrm{sel}) ; 1_{\mathrm{SR}} \quad=$ luas total lapang pandang Sedgwick Rafter $\left(1000 \mathrm{~mm}^{2}\right)$; lp = luas lapang pandang Sedgwick Rafter yang diamati $\left(\mathrm{mm}^{2}\right) ; \mathrm{V}_{1} \quad=$ volume air contoh yang tersaring $(\mathrm{ml}) ; \mathrm{V}_{\mathrm{SRC}}=$ volume sedgwick rafter $(1 \mathrm{ml}) ; \mathrm{V}_{\mathrm{T}}=$ volume air yang disaring (l).

\subsection{Pengambilan Parameter in situ}

Parameter in situ yang diambil dalam penelitian adalah suhu, salinitas, oksigen terlarut (DO), BOD dan derajat keasaman (pH). Pengambilan parameter in situ tersebut dilakukan secara vertikal dari permukaan sampai dasar perairan dengan menggunakan MIDAS CTD (Conductivity Temperatur Depth) .

Selain parameter di atas diambil juga data arah dan kecepatan arus. Data arus, baik arah dan kecepatannya, diperoleh secara insitu dengan bantuan current meter propeller-type. Penurunan current meter dilakukan secara perlahan mulai dari permukaan hingga dasar perairan. Hal tersebut dilakukan agar diperoleh data arah dan kecepatan arus pada setiap layer kedalaman perairan. Sedangkan data pasang surut diperoleh secara sekunder, yaitu melalui data hidro-klimatologi.

\subsection{Analisis Data}

Komposisi (jenis dan kelimpahan) fitoplankton yang diperoleh digunakan untuk melihat tingkat pencemaran dengan menggunakan indeks saprobitas. Penentuan Indeks saprobik dihitung dengan menggunakan rumus dari Drescher \& Mark (1974).

$$
\mathrm{SI}=(\mathrm{C}+3 \mathrm{D}+\mathrm{B}-3 \mathrm{~A}) /(\mathrm{A}+\mathrm{B}+\mathrm{C}+\mathrm{D})
$$

Keterangan: $\mathrm{SI}=$ Saprobik Indeks; $\mathrm{A}=$ Jumlah genus organisme polisaprobik: $\mathrm{B}=$ Jumlah genus organisme $\alpha$-mesosaprobik; C
$=$ Jumlah genus organisme $\beta$-mesosaprobik; $\mathrm{D}=$ Jumlah genus organisme oligosaprobik.

Komposisi plankton pada perairan Sungai Musi bagian hilir ditampilkan dalam bentuk tabel dan grafik dengan menggunakan bantuan Microsoft Excel.

\section{HASIL DAN PEMBAHASAN}

\subsection{Komposisi Fitoplankton}

Berdasarkan hasil identifikasi, ditemukan 14 jenis fitoplankton yang terbagi atas 3 Kelas, yaitu Kelas Bacillariophyceae 79\% (Bacillaria, Chaetoceros, Coscinodiscus, Ditylum, Guinardia, Hemiaulus, Lauderia, Nitzschia. Rhizosolenia, Skeletonema, Thalassionema), Kelas Chlorophyceae 7\% (Scenedesmus) dan Kelas Cyanophyceae 14\% (Oscillatoria dan Spirulina). Hasil ini menunjukkan bahwa perairan Sungai Musi bagian hilir hingga ke Muara memiliki komposisi fitoplankton yang berasal dari laut (haliplankton), plankton air tawar (limnoplankton) dan plankton air payau/perairan pantai (plankton neritik). Hal ini disebabkan karena letak pengambilan sampel yang berada di sungai Musi (perairan tawar), di sekitar mulut sungai (perairan payau), dan berada sedikit di luar muara menuju laut sehingga fitoplankton yang ditemukan merupakan jenis dari ketiga habitat tersebut.

Pada dasarnya kehidupan plankton sangat dipengaruhi oleh keadaan lingkungan, termasuk faktor fisika dan kimia perairannya. Faktor fisika mencakup kecepatan arus, kecerahan, suhu, warna, bau dan rasa. Faktor kimia mencakup $\mathrm{pH}$, oksigen terlarut, $\mathrm{CO}_{2}$, fosfat, nitrat, amoniak, garam-garam mineral, dan salinitas (Sachlan, 1982). Faktor-faktor tersebut sangat menentukan jenis, kesuburan serta sifat perairan tersebut. Kesuburan dan sifat suatu perairan juga dapat dilihat dari jenis dan populasi plankton yang ada di perairan tersebut. Berikut diagram pie komposisi kelas fitoplankton dan jenis-jenis fitoplankton yang ditemukan di Sungai Musi bagian hilir dapat dilihat pada Gambar 2. 


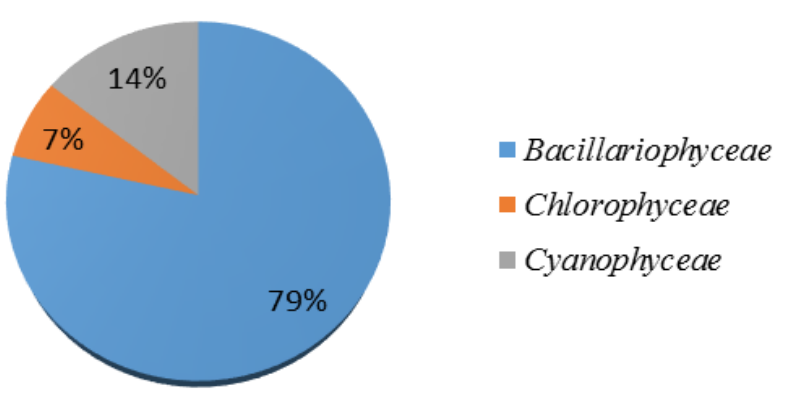

Gambar 2. Komposisi kelas fitoplankton di Perairan Sungai Musi.

Figure 2. Composition of phytoplankton class in the waters of the Musi River.

Bacillariophyceae dijumpai memiliki jumlah genera dan kelimpahan yang terbesar dibanding kelompok lainnya. Hal ini disebabkan karena kelas Bacillariophyceae mampu menyesuaikan diri dengan kondisi lingkungan sekitarnya dibandingkan dengan kelas lainnya. Menurut Arinardi et al. (1997), kelas Bacillariophyceae lebih mampu beradaptasi dengan kondisi lingkungan yang ada, kelas ini bersifat kosmopolitan serta mempunyai toleransi dan daya adaptasi yang tinggi. Keadaan ini sering juga dijumpai di wilayah perairan pesisir Kabupaten
Banyuasin Provinsi Sumatra Selatan maupun perairan wilayah Indonesia lainnya (Haumahu, 2004; Aryawati et al., 2005; Fathi \& Al-Kahtani, 2009; Ismunarti, 2013; Thoha \& Aryawati, 2014; Aryawati et al., 2017; Aryawati et al., 2018; Arazi et al., 2019).

\subsection{Kelimpahan Fitoplankton}

Kelimpahan merupakan hubungan antara jumlah fitoplankton dalam satuan volume. Kelimpahan dapat menunjukkan banyaknya fitoplankton jenis tertentu atau banyaknya fitoplankton yang terdapat dalam satuan volume di suatu perairan. Kelimpahan fitoplankton di perairan Sungai Musi bagian hilir pada saat penelitian berkisar antara 123$2581 \mathrm{sel} / \mathrm{l}$ (Gambar 3), dengan kelimpahan rata-rata sebesar $1397 \mathrm{sel} / 1$.

Bila ditinjau kelimpahan pada setiap stasiun, secara umum kelimpahan fitoplankton meningkat seiring dengan semakin jauhnya lokasi stasiun dari hulu. Stasiun 1, 2, 3, 4, 5, 6, dan 7 berada di sungai bagian dalam, yang lebih dekat ke arah hulu. Stasiun 8, 9, 10, 11, dan 12 berada di dekat muara. Stasiun 13 dan 14 berada di perairan yang banyak dipengaruhi laut. Stasiun 12 memiliki kelimpahan tertinggi yaitu 2.581 sel/liter. Stasiun 8, 9, 10, 11, 12 dan 14

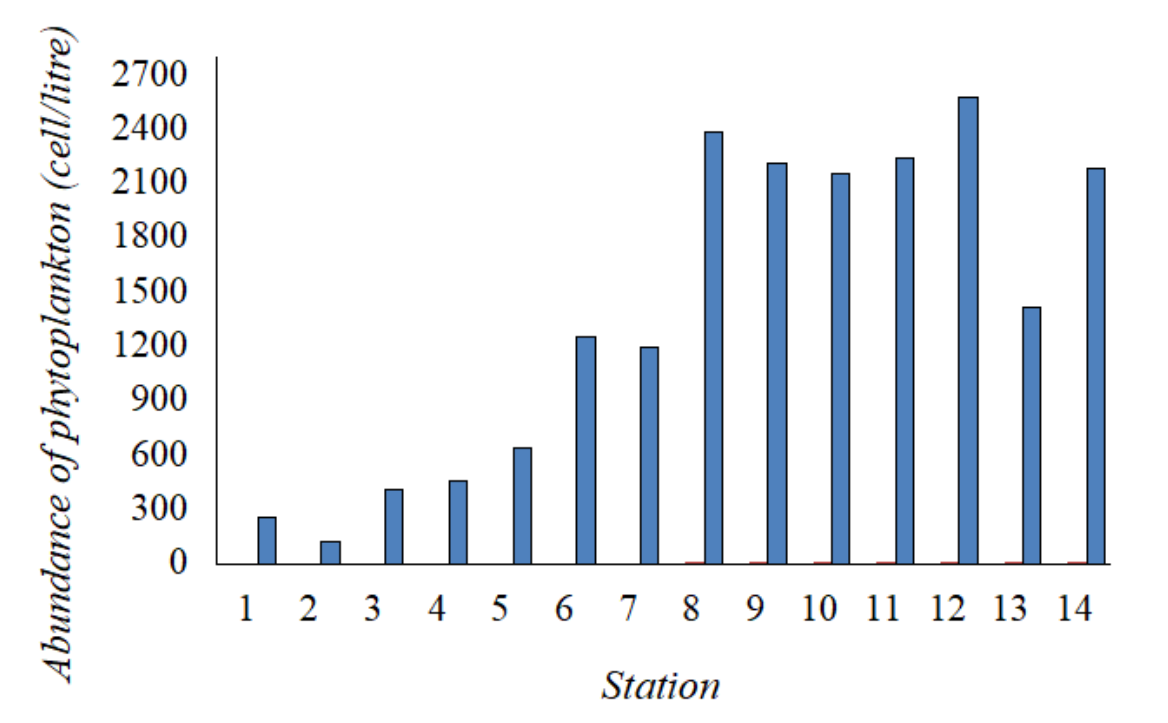

Gambar 3. Kelimpahan fitoplankton di sungai Musi.

Figure 3. Abundance of phytoplankton in The Musi river. 


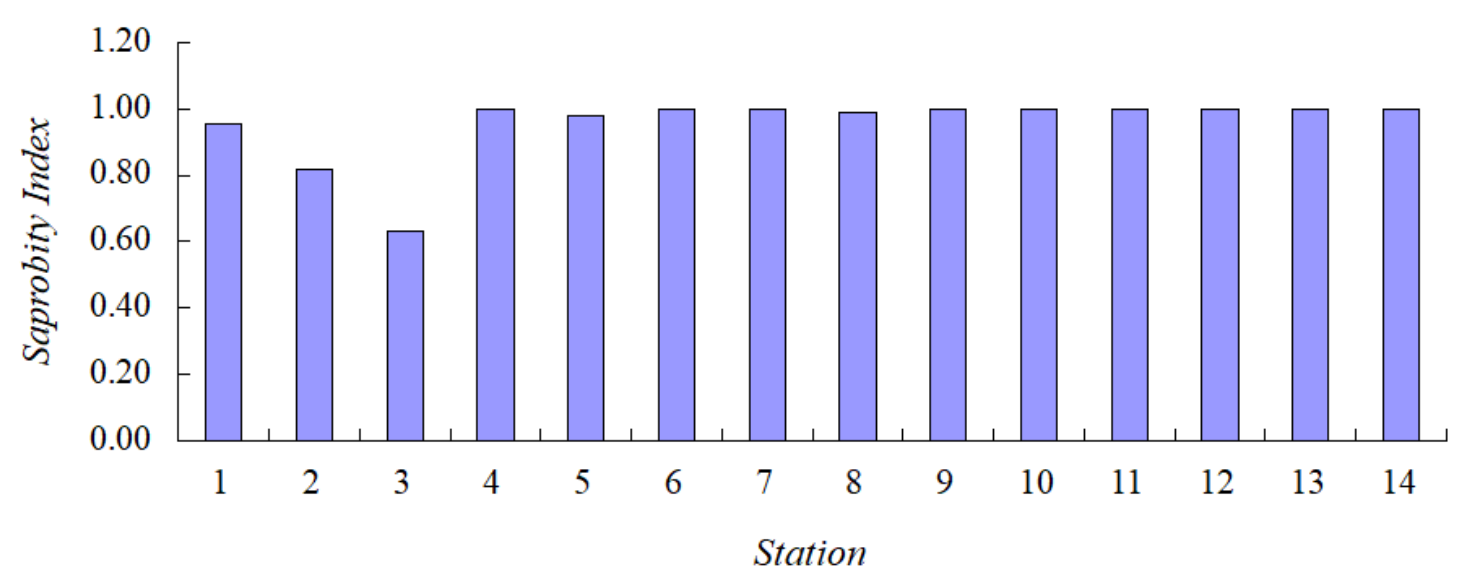

Gambar 4. Nilai Indeks Saprobitas di Sungai Musi.

Figure 4. Saprobitas Index Value in Musi River.

tergolong pada perairan dengan tingkat kesuburan atau produktivitas primer yang sedang dan memiliki kelimpahan yang lebih tinggi dibandingkan stasiun lainnya. Hal ini kemungkinan disebabkan letak stasiun yang berada pada muara sungai/mulut sungai, merupakan tempat bertemunya air tawar dan air laut sehingga menjadi tempat pertemuan antara nutrien yang terbawa dari air sungai dan nutrien yang terbawa dari air laut. Dengan demikian dapat diasumsikan bahwa pada stasiun-stasiun ini akan dijumpai fitoplankton dengan jumlah yang lebih banyak.

\subsection{Indeks Saprobik di Perairan Sungai Musi Bagian Hilir}

Analisis Indeks Saprobik dari data fitoplankton yang diperoleh di perairan Sungai Musi bagian hilir, memiliki nilai yang berkisar antara 0,63-1 pada 14 stasiun pengamatan. Tidak terdapat perbedaan nilai indeks saprobitas yang nyata pada setiap stasiun (Gambar 4). Secara umum keempat belas stasiun memiliki nilai indeks saprobitas perairan yang cenderung sama. Nilai Indeks Saprobik tersebut, menurut Drescher \& Mark (1974) termasuk pada fase saprobik $\beta$ Mesosaprobik, sehingga digolongkan pada tingkat pencemaran ringan atau rendah.
Dahuri
(1995)
menyatakan

mesosaprobik, merupakan zona perairan tercemar sedang, komponen bahan organik lebih sederhana, kandungan oksigen lebih tinggi dibandingkan pada zona polisaprobik. Pada zona ini terjadi proses mineralisasi oleh bakteri (konversi bahan organik menjadi bahan anorganik) yang hasilnya akan dimanfaatkan bagi pertumbuhan alga dan hewan yang toleran pada zona ini. Perairan $\beta$-mesosaprobik merupakan perairan tercemar ringan; fitoplankton didominasi oleh Chlorophyceae dan diatom, serta Euglenophyceae mulai jarang/menghilang, dengan kandungan oksigen terlarut mulai meningkat. Suwondo et al. (2004) menyebutkan bahwa suatu limbah bahan organik yang masuk ke dalam perairan akan menimbulkan pencemaran sedang, karena akan memberikan tekanan yang berat terhadap organisme plankton.

Meiwinda et al. (2015) telah melakukan penelitian di Sungai Musi, khususnya di Kecamatan Gandus Kota Palembang yang menunjukkan hasil bahwa di wilayah ini telah terjadi pencemaran perairan yang termasuk dalam kategori sedang, hal ini karena adanya pencemaran bahan organik dari perairan di sekitar Gandus. Pencemaran di wilayah ini diduga karena padatnya penduduk yang dapat menghasilkan limbah organik dan adanya perusahaan-perusahaan yang menghasilkan limbah berupa bahan organik. Hal ini sejalan 
dengan penelitian yang dilakukan oleh Zulkifli et al. (2009), berdasarkan status saprobik, perairan muara Sungai Musi tergolong tercemar ringan hingga sedang. Kondisi di perairan Sungai Musi bagian hilir memiliki kemiripan dengan kondisi di muara Sungai Morodemak, berdasarkan indeks saprobik memperlihatkan kondisi perairan muara sungai Morodemak tercemar ringan sampai sedang (Suryanti, 2008). Penelitian yang dilakukan Labupili et al. (2018) di beberapa pelabuhan di Bali dengan menggunakan indeks saprobik, menunjukkan ada perbedaan tingkat pencemaran pada skala pelabuhan yang berbeda, mulai dari tidak tercemar hingga tercemar sedang.

\subsection{Kondisi Parameter Lingkungan Perairan}

Kondisi parameter lingkungan perairan umumnya ditinjau dari parameter fisika dan kimia perairan. Parameter fisika diantaranya adalah temperatur dan salinitas, sedangkan parameter kimia adalah $\mathrm{pH}$, oksigen terlarut (DO), Biological Oxygen Demand (BOD), nitrat, fosfat dan ammonia.

Secara umum kualitas air Sungai Musi bagian hilir dikatakan baik dan menunjang untuk pertumbuhan dan perkembangan organisme perairan, khususnya fitoplankton. Nilai suhu di perairan Sungai Musi bagian hilir pada saat penelitian berkisar antara $29,8-30,5^{\circ} \mathrm{C}$. Suhu berperan penting dalam metabolisme organisme perairan. Menurut Hutabarat \& Evans (1986), jika suhu air berkisar antara 24-32 ${ }^{0} \mathrm{C}$ maka plankton dapat tumbuh dan berkembang biak dengan baik. Salinitas pada lokasi penelitian berkisar antara 0,0529,95\%o. Kisaran salinitas dijumpai sangat lebar karena penelitian dilakukan di Sungai Musi bagian hilir hingga muara.

Nilai $\mathrm{pH}$ di perairan Sungai Musi bagian hilir berkisar antara 6-7 dengan ratarata 6,36. Kondisi perairan pada saat penelitian dalam keadaan normal cenderung asam. Kondisi asam maupun basa akan membahayakan kelangsungan hidup organisme karena akan menyebabkan terjadinya gangguan metabolisme dan respirasi. Nilai oksigen terlarut (DO) dijumpai berkisar antara 3,61-7,52 mg/l dengan rata-rata $4,56 \mathrm{mg} / \mathrm{l}$. Nilai DO pada perairan ini tergolong cukup baik untuk organisme. Kandungan DO lebih dari $5 \mathrm{mg} / \mathrm{L}$ menandakan tingkat pencemaran pada perairan tersebut rendah, sedangkan jika kandungan DO kurang dari $5 \mathrm{~g} / 1$ maka perairan tersebut memiliki tingkat pencemaran sedang. Wardoyo (1982) menjelaskan bahwa kehidupan ikan dan kebanyakan organisme perairan lainnya masih dapat hidup dengan layak jika kandungan oksigen terlarut perairan lebih besar dari $3 \mathrm{mg} / \mathrm{L}$. Konsentrasi BOD berkisar antara $0,35-1,57 \mathrm{mg} / 1$ dengan rata-rata 0,78 $\mathrm{mg} / \mathrm{l}$ sehingga nilai BOD ini dapat dikatakan baik.

Kondisi nutrien di perairan Sungai Musi bagian hilir khususnya nitrat, fosfat dan ammonia, memiliki konsentrasi nilai yang bervariasi pada setiap stasiunnya. Konsentrasi nitrat berkisar antara 0,03-2,04 $\mathrm{mg} / \mathrm{l}$ dengan rata-rata $0,86 \mathrm{mg} / \mathrm{l}$, konsentrasi ammonia berkisar antara $0,02-0,41 \mathrm{mg} / \mathrm{l}$ dengan rata-rata $0,14 \mathrm{mg} / 1$ dan konsentrasi fosfat berkisar antara $0,23-0,65 \mathrm{mg} / \mathrm{l}$ dengan rata-rata $0,16 \mathrm{mg} / \mathrm{l}$. Konsentrasi nutrien di wilayah ini tergolong tinggi, diduga karena merupakan daerah yang mendapat akumulasi kandungan hara akibat banyaknya aktivitas dari daerah sekitar.

\section{KESIMPULAN}

Nilai Indeks Saprobik merata pada hampir seluruh stasiun sehingga perairan Sungai Musi bagian hilir dikategorikan pada fase saprobik, yaitu $\beta$-Mesosaprobik, dan termasuk dalam perairan dengan tingkat pencemaran ringan atau rendah.

\section{UCAPAN TERIMA KASIH}

Ucapan terima kasih penulis sampaikan kepada Kemenristek-Dikti dan 
Universitas Sriwijaya yang telah memberi dukungan terhadap kegiatan ini.

\section{DAFTAR PUSTAKA}

American Public Health Association (APHA). 1992. Standard methods for the examination of water and wastewater. 19th edition. American Public Health Association, Washington, D.C. 76 p.

Arazi, R, Isnaini, \& Fauziyah. 2019. Struktur komunitas dan kelimpahan fitoplankton serta keterkaitannya dengan parameter fisika kimia di Perairan Pesisir Banyuasin Kabupaten Banyuasin. J. Penelitian Sains, 21(1): 1-8. https://doi.org/10.26554/jps.v21i1.52 4

Arinardi, O.H., A.B Sutomo, S.A. Yusuf, Trimaningsih, E. Asnaryanti, \& S.H. Riyono. 1997. Kisaran kelimpahan dan komposisi plankton predominan di perairan Kawasan Timur Indonesia. Pusat Penelitian dan Pengembangan Oseanologi Lembaga Ilmu Pengetahuan Indonesia. Jakarta. $140 \mathrm{p}$.

Aryawati, R., H. Surbakti, \& T.Z. Ulqodry. 2005. Hubungan kondisi oseanografi dengan kelimpahan fitoplankton di perairan Banyuasin. Pemanfaatan dan Pengelolaan Perairan Umum secara Terpadu bagi Generasi Sekarang dan Mendatang. Palembang: BRPPU. 105 p.

Aryawati, R, Bengen D.G, T. Prartono, \& H. Zulkifli. 2017. Abundance of phytoplankton in the coastal waters of South Sumatera. Ilmu Kelautan: Indonesian J. of Marine Science, 22(1): 31-39.

https://doi.org/10.14710/ik.ijms.22.1. 31-39

Aryawati, R, T.Z. Ulqodry, H. Surbakti, \& E.N. Ningsih. 2018. Populasi fitoplankton Skeletonema di Estuaria
Banyuasin, Sumatera Selatan. J. Ilmu dan Teknologi Kelautan Tropis, 10(2): 269 - 275.

https://doi.org/10.29244/jitkt.v10i2.18 730

Drescher, T.G.N. \& H. van der Mark. 1974. A simplified method for the assessment of quality of fresh \& Slightly Brackish Water. Hydrobiologia, 48(3): 199-201. https://edepot.wur.nl/399866

Fathi, A.A. \& M.A. Al-Kahtani. 2009. Water quality and planktonic communities in Al-Khadoud Spring, AlHassa,Saudi Arabia. American J. of Environmental Sciences 5, (3): 434443. https://doi.org/10.3844/ajessp.2009.4 34.443

Haumahu, S. 2004. Distribusi spasial fitoplankton di Teluk Ambon bagian dalam. Ichtyos, 3: 91-98. https://ejournal.undip.ac.id/index.php/ ijms/article/viewFile/2269/1990

Hutabarat, S. \& M. Evans. 1986. Kunci Identifikasi Zooplankton. UI Press. Jakarta. 98 p.

Hutabarat, S., P. Soedarsono, \& I. Cahyaningtyas. 2013. Studi analisa plankton untuk menentukan tingkat pencemaran di muara Sungai Babon Semarang. J. of Management of Aquatic Resources, 2(3): 74-84. https://doi.org/10.14710/marj.v2i3.41 85

Ismunarti, D.H. 2013. Analisis komponen utama pada hubungan distribusi spasial komunitas fitoplankton dan faktor lingkungan. Ilmu Kelautan: Indonesian J. of Marine Science, 18(1): 14-19. https://doi.org/10.14710/ik.ijms.18.1. 14-19

Labupili, A.G.A., I.J.P. Dewi, \& A. Heriansyah. 2018. Plankton sebagai indikator pencemaran perairan di kawasan pelabuhan yang dijadikan tempat pendaratan ikan di Bali. $J$. 
Kelautan dan Perikanan Terapan, 1(01): 22-29.

https://doi.org/10.15578/jkpt.v1i1.724 9

Meiwinda, E.R., Marsi, \& Arinafril. 2015. Komunitas plankton sebagai bioindikator pencemaran perairan Sungai Musi di Kecamatan Gandus dan Kertapati berdasarkan pasang surut. J. Akuakultur Rawa Indonesia, 3(2): 26-35. https://doi.org/10.36706/jari.v3i2.443 9

Newell, G.E. \& R.C. Newell. 1977. Marine Plankton; A Practical Guide. Hutchinson \& Co Ltd. London. 244 p.

Nontji, A. 2005. Laut Nusantara. Penerbit Djambatan. Jakarta. 372 p.

Nybakken, J.W. 1992. Biologi Laut: Suatu Pendekatan Ekologis. Diterjemahkan oleh H. M. Eidman, Koesoebiano, D. G. Bengen, M. Hutomo dan S.Subarjo. Jakarta. PT. Gramedia Pustaka Utama. 459 p.

Pemprov Sumsel. 1997. Laporan Tahunan Program Kali Bersih Sungai Musi Periode 1996-1997. Palembang. Pemprov Sumatra Selatan. 123 p.

Rasyid, H.A., D. Purnama \& A.B. Kusuma. 2018. Pemanfaatan fitoplankton sebagai bioindikator kualitas air di perairan muara Sungai Hitam Kabupaten Bengkulu Tengah Provinsi Bengkulu. J. Enggano, 3(1): 39-51. https://doi.org/10.31186/jenggano.3.1 .39-51

Rudiyanti, S. 2009. Kualitas perairan Sungai Banger Pekalongan berdasarkan indikator biologis. J. Saintek Perikanan, 4(2): 46-52. https://doi.org/10.14710/ijfst.4.2.4652

Sachlan, M. 1982. Planktonologi. Fakultas Peternakan dan Perikanan Universitas Diponegoro. Semarang. 177 p.

Standar Nasional Indonesia (SNI). 2005. No. 06-6989-1-31: Cara uji kadar fosfat dengan spektrofotometer secara asam askorbat. Badan Standardisasi Nasional (BSN). Jakarta. 6 p.

Standar Nasional Indonesia (SNI). 2011. No. 6989.79: Cara uji nitrat $\left(\mathrm{No}_{3}-\mathrm{N}\right)$ dengan spektrofotometer UV-visibel secara reduksi kadmium. Badan Standardisasi Nasional (BSN). Jakarta. 12 p.

Suwondo, E. Febrita, Dessy, \& M. Alpusari. 2004. Kualitas biologi perairan Sungai Senapelan, Sago dan Sail di kota Pekanbaru Berdasarkan bioindikator plankton dan bentos. $J$. Biogenesis, 1(1): 15-20.

https://biogenesis.ejournal.unri.ac.id/i ndex.php/JPSB/article/view/1835

Thoha, H \& R. Aryawati. 2014. Kondisi Fitoplankton di Perairan Teluk Jakarta. Seminar Nasional MIPA: Peran MIPA dalam pengelolaan sumberdaya alam untuk kemakmuran bangsa. 516-526 pp.

Tomas, C.R. 1997. Identifying Marine Phyitoplankton. Academic Press. California. $858 \mathrm{p}$.

Suryanti. 2008. Kajian tingkat saprobitas di muara Sungai Morodemak pada saat pasang dan surut. J. Saintek Perikanan, 4 (2): 76-83. https://doi.org/10.14710/ijfst.4.1.7683

Wardoyo, S.T.H. 1982. Pengelolaan Kualitas Air Pusat Studi Pengelolaan Sumber Daya Lingkungan. IPB. Bogor. 42 p.

Zulkifli, H., Husnah, M.R. Ridho \& S. Juanda. 2009. Status kualitas Sungai Musi bagian hilir ditinjau dari komunitas fitoplankton. Berk. Penel. Hayati, 15: 5-9.

https://berkalahayati.org/files/journals /1/articles/85/submission/85-231-1SM.pdf

Received : 19 March 2019

Reviewed : 01 July 2019

Accepted : 18 April 2020 
